MATEC Web of Conferences 15, 01038 (2014)

DOI: $10.1051 /$ matecconf/ 20141501038

(C) Owned by the authors, published by EDP Sciences, 2014

\title{
Night-Time Highway Construction or Maintenance/Upgrading Works: An Analysis
}

\author{
A.M. Ab Wahid ${ }^{1}$, A.H. Abdul Tharim², A. Ahmad ${ }^{3}$, N.A. Ismail ${ }^{4}$, H. Zainol ${ }^{5}$ \\ 1, 2, 3,4,5 Department of Quantity Surveying, Faculty Architecture Planning and Surveying,UiTM Perak, \\ 32610, Bandar Baru Seri Iskandar, Perak, Malaysia
}

\begin{abstract}
This paper presents the analysis of interview sessions conducted with the general objective of studying night-time highway construction or maintenance/upgrading works. This includes any work; construction, maintenance or upgrading, that involves the closure of highway lanes and traffic mitigation. Such works might be disadvantageous to be conducted during daytime, thus requiring them to be conducted at night. Data were collected by conducting interviews to relevant industry players with the objective of identifying reasons for such works to be conducted at night. The answers obtained were the gathered and the most famous themes are selected.
\end{abstract}

\section{Introduction}

Traffic congestion is a normal occurrence in the roads of Malaysia, especially in major towns such Kuala Lumpur, Georgetown, and many more. Other than in towns, congestion also occurs in highways, especially during peak hours, when road users commute from their office to their homes. Any highway construction or maintenance/upgrading works will only make things worse as it may lead them to spend more hours on the road since such works would require the closing of lanes and other problems, which will increase traffic congestion. Contractors and also local authorities should ensure that such problems do not exist and plan how to avoid road users from being the victim when this occurs. Night-time highway construction or maintenance/upgrading works is not the best option for all cases, and should only be used when necessary. Therefore, this study is crucial as it offers contractors a basis on what to consider when deciding whether to go for night-time highway construction or maintenance/upgrading works or not.

\section{Literature Review}

The road construction site itself is considered as a hazardous place to work at [1] and accident can occur at any time and in many ways. The importance of roads and highways as a means to deliver goods and increase the country's income cannot be denied. As a result, roads and highways should be constantly maintained and if necessary, upgraded, without interfering their normal use and also safe to use. According to Abraham, Spadaccini, Burgess, Miller, and Valentin [2] the main reason for works to be conducted at night-time is to avoid tafficcongestion from occurring, especially on busy roads and during rush hours. Night-timehighway construction or maintenance/upgrading works may seem as the best option compared to day time works in order to avoid traffic congestion problems especially when it comes to major roads and highways. Choosing to conduct road construction activities at night will 
have its implication due to its different working conditions compared to working during the day. Even if traffic congestion problems may be solved, other problems might arise thus increasing the risk of other types of incident to occur.

Table 1: Implication of conducting road construction activities at night compared to day time operation

\begin{tabular}{|c|c|}
\hline Implication & $\begin{array}{l}\text { Explanation } \\
\end{array}$ \\
\hline A & $\begin{array}{l}\text { Like all construction site, safety is of the most important factor to be looked at. Failure to ensure } \\
\text { safety will lead to accidents and even death to occur, even at a road works site. A night time road } \\
\text { construction zone should ensure the safety of works, workers or the general public. According to } \\
\text { Elrahman [4], an analysis had shown that crash rates per } 100 \text { hours of road work per mile were } \\
\text { much higher during the day compared to the ones at night and that there is a slightly greater } \\
\text { percentage of severe night time crashes before night work and during night work as compared to } \\
\text { day time crashes. However, lower traffic demand at night can result in fewer crashes over the } \\
\text { duration of the project. }\end{array}$ \\
\hline Productivity & $\begin{array}{l}\text { Several studies have been conducted and most of them have concluded that there are no real } \\
\text { substantial differences in terms of worker productivity between night time and day time } \\
\text { construction works }[3,5,6] \text {. However, Hinze and Carlisle [3] did state that communication } \\
\text { between the client's, contractor's and site personnel would become a problem during night time } \\
\text { since not all of them will be working at that time, thus making decision making difficult and } \\
\text { leading to works being delayed and resulting to works being put on hold. }\end{array}$ \\
\hline Quality & $\begin{array}{l}\text { According to Abraham et. al. [2], quality of works would be affected at night due to inadequate } \\
\text { lighting. Besides that, Park,Douglas, Griffithand Haas [7] reported that paving operations that the } \\
\text { quality of works were } 3 \% \text { less at night than during the day. On the other hand, according to } \\
\text { Elrahman [4], Hacher and Taylor (1) and Al-Kaisy and Nassar [8] had found out that the cooler } \\
\text { condition at associated with working at night can actually increase night time work quality. The } \\
\text { effect of quality during night time construction is difficult to conclude since each work has its } \\
\text { own specification and requirement. Price [9] confirmed that roller marks for paving project } \\
\text { became more apparent at night, which may be caused by the rapid cooling at night, where on the } \\
\text { other hand will result to placement of certain types of Portland cement paving to become easier. }\end{array}$ \\
\hline Workers & $\begin{array}{l}\text { There is only a small number of research conducted on the physical and mental effects of night } \\
\text { time works towards the workers. Carpentier and Cazamian [10] stated that the disruption of the } \\
\text { normal human biological sleep cycle may lead to various physiological and psychological } \\
\text { stresses to a person, while according to Holguin-Veras,Baker,Medina,and Sackey [11] mentioned } \\
\text { that } 20 \% \text { of workers engaged in night shift activities report sleep-related disorders. }\end{array}$ \\
\hline
\end{tabular}

\section{Research Methodology}

As mentioned earlier, data were collected through interviews in order to understand the whole idea and implementation of highway construction or maintenance/upgrading works during night-time in the Malaysian construction industry. For the purpose of this study, 30 interviewees were selected from contractors, consultants and road users of PLUS highway from Perak to Penang, including a few interviewees from highway related research centers. The theme of the answer given by the interviewees were then abstracted and compiled. They are the arranged and listed from the most famous and common theme to the least famous theme. Themes that have the most frequency and famous given by the interviewees were discussed and analysed in this study while the least famous were not discussed.

\section{Data Analysis}

In order to identifying reasons for night-time highway construction or maintenance/upgrading works, structured interviews with 4 questions were conducted, and then the most famous answers (themes) were gathered and ranked and explained in this section. The least famous themes were not taken and explained here since not all the interviewees agreed on them. The following table indicates the summary of model for data collection for this research. 


\subsection{The main reasons for night-time highway construction or maintenance/upgrading works}

Table 2: Reasons for night-time highway construction or maintenance/upgrading works

\begin{tabular}{|c|c|c|}
\hline $\begin{array}{c}\text { Ranking } \\
\text { No. }\end{array}$ & Theme & Explanation \\
\hline 1 & Saving time & $\begin{array}{l}\text { Interviewees were asked the main reasons for night-time highway construction or } \\
\text { maintenance/upgrading works. The main theme found in the response for the } \\
\text { question was that night-time highway construction or maintenance/upgrading } \\
\text { works were conducted due to the intention of reducing the construction period. } \\
\text { Construction performed both day and night will be able to increase the output } \\
\text { hours within a } 24 \text {-hour period compared to working during the normal daytime } \\
\text { working hours only. For example, an interviewee stated if working during daytime } \\
\text { only, the output hours that can be achieved is around } 8 \text { hours only ( } 8.00 \text { a.m. to } \\
5.00 \text { p.m.) within } 24 \text { hours ( } 1 \text { day). On the other hand, by working both day and } \\
\text { night, more working hours can be achieved thus increasing the output for a day } \\
\text { where works can be done during the } 8 \text { hours in the day plus the extra working } \\
\text { hours at night, usually around } 4 \text {, which will lead to the output of } 12 \text { hours within } \\
\text { the } 24 \text { hours ( } 1 \text { day) (output per day). The increase in output hours will also } \\
\text { increase the number of works that can be accomplished in a day thus reducing the } \\
\text { total working days of a project. This is very important especially for projects with } \\
\text { tight datelines and short construction period. }\end{array}$ \\
\hline 2 & $\begin{array}{l}\text { Reduce traffic } \\
\text { congestion }\end{array}$ & $\begin{array}{l}\text { The other theme obtained from main reason for conducting highway construction } \\
\text { or maintenance/upgrading works during night-time is to reduce and if possible to } \\
\text { avoid altogether traffic congestion problem arising from daytime works. Based on } \\
\text { the interviewee's comments, they stated that some works cannot be performed } \\
\text { during the day since it involves road closures or traffic divergence which could } \\
\text { possibly lead to traffic congestion problems during working hours and road users } \\
\text { arriving late to their destination. In order to avoid such problems from occurring } \\
\text { during the busy working hours a day, works can only be performed at night due the } \\
\text { lower volume of traffic and also people are less rushing at night. If there is a need } \\
\text { to perform road closures or traffic divergence at night, the road users will not be } \\
\text { severely affected since people are normally not in a rush at night compared to } \\
\text { during the day. }\end{array}$ \\
\hline 3 & $\begin{array}{l}\text { Ease of } \\
\text { conducting } \\
\text { works }\end{array}$ & $\begin{array}{l}\text { Some works can also be performed much easier at night especially when it } \\
\text { involves the transportation of large components or the use of large machineries. }\end{array}$ \\
\hline
\end{tabular}

\subsection{The effects of night-time highway construction or maintenance/upgrading works to safety, productivity, quality and the workers}

Table 3: Effectsto safety, productivity, quality and the workers

\begin{tabular}{|c|c|l|}
\hline $\begin{array}{c}\text { Ranking } \\
\text { No. }\end{array}$ & Theme & \multicolumn{1}{c|}{ Explanation } \\
\hline \multirow{1}{*}{1} & $\begin{array}{c}\text { Safety } \\
\text { - for workers } \\
\text { - for road users }\end{array}$ & $\begin{array}{l}\text { When talking about safety, the interviewees mentioned that contractors should } \\
\text { increase the safety aspect especially in terms of lighting and other relevant visual } \\
\text { aspects of safety due to the reduce visibility associated to working at night-time. } \\
\text { In the interview, the most common theme identified is that the most important } \\
\text { safety considerations for night-time works can be focused into two groups. First of } \\
\text { all is the safety of the workers. Workers should wear appropriate clothings in } \\
\text { order for them to be visibly clear to road users at night. This is to avoid them from } \\
\text { being hit by incoming traffic. The site should also be well lighted so that the } \\
\text { workers can see everything in from of them and can also clearly see the works that } \\
\text { they are doing. Secondly, the safety of the road users should also be emphasized. } \\
\text { Road users should be warned in advance of any construction works and should } \\
\text { clearly see everything in their path. These can be achieved by adequate lighting }\end{array}$ \\
\hline
\end{tabular}




\begin{tabular}{|c|c|c|}
\hline & & $\begin{array}{l}\text { and also making sure that everything around the construction zone is light } \\
\text { reflective, ranging from the clothings of the workers, the signs used, the barriers } \\
\text { used, machineries and everything else. By doing so, the road users are aware of } \\
\text { their surrounding and clearly see everything thus reducing the possibility of } \\
\text { accidents from occurring which will jeopardize the life of the road users. The } \\
\text { other theme found in the interviewee is that the protection of the works on site } \\
\text { from accidents is also important, but not as important as protecting people's } \\
\text { wellbeing and life. }\end{array}$ \\
\hline 2 & $\begin{array}{l}\text { Productivity of } \\
\text { workers }\end{array}$ & $\begin{array}{l}\text { It is found that the productivity of workers will be affected and is in direct relation } \\
\text { to the effect of night-time highway construction or maintenance/upgrading works } \\
\text { to workers themselves as some workers are not used to working at night, while } \\
\text { some might have difficulty seeing at night, while others are too tired since they } \\
\text { have been working all day long. This shows that night-time highway construction } \\
\text { or maintenance/upgrading works will have an affect towards the productivity of } \\
\text { workers. }\end{array}$ \\
\hline 3 & $\begin{array}{l}\text { Quality of } \\
\text { works }\end{array}$ & $\begin{array}{l}\text { When it comes to the quality or works of night-time highway construction or } \\
\text { maintenance/upgrading works, there is a slight effect towards the drying period of } \\
\text { surfacing of road works. This is due to the cool and humid condition at night } \\
\text { compared to the sunny, hot and dry condition of the day. For other works such as } \\
\text { demolishing existing road, placing up new permanent road dividers and permanent } \\
\text { road signs, hoisting up pre-cast road structures and other works that doesn't } \\
\text { involve drying of works are not really affected. The issue of inadequate lighting } \\
\text { also doesn't affect the quality of works rather than the safety of works. This is } \\
\text { mainly because night-time highway construction works are normally large and } \\
\text { heavy and doesn't really involve a high degree of precision works such as } \\
\text { painting. }\end{array}$ \\
\hline 4 & $\begin{array}{l}\text { Physical and } \\
\text { psychological } \\
\text { effect towards } \\
\text { workers }\end{array}$ & $\begin{array}{l}\text { When asked on the effects of night-time works towards the workers themselves, } \\
\text { the theme of answers varies according to the type of work. For workers that have } \\
\text { to work from daytime until night-time, they will have both physical and } \\
\text { psychological effect. This is because, eventhough they are paid overtime, their } \\
\text { body will be exhausted due to the long working hours and their mind will be } \\
\text { demoralised since the night-time that they normally use to spend to rest and be } \\
\text { with their families are now used to work. The same physical problems do not } \\
\text { occur to workers working in shifts do not really affect for night-time workers who } \\
\text { works in shifts since they have rested enough during the day, but the same } \\
\text { psychological problem might still persist. This will result to a less productive work } \\
\text { output per hour by the workers at night as mentioned earlier. }\end{array}$ \\
\hline
\end{tabular}

\subsection{Safety measures of night-time highway construction or maintenance/upgrading works}

Table 4: Safety measures

\begin{tabular}{|c|c|l|}
\hline $\begin{array}{c}\text { Ranking } \\
\text { No. }\end{array}$ & Theme & \multicolumn{1}{c|}{ Explanation } \\
\hline Lighting & $\begin{array}{l}\text { In terms of safety, the most common theme obtained from the respondents is that } \\
\text { the essence of safety features of night-time highway construction or } \\
\text { maintenance/upgrading works is similar to day-time construction, but extreme } \\
\text { emphasize must be the give towards lighting aspect of the works. As mentioned } \\
\text { earlier, due to the low visibility problems associated with working in night-time, } \\
\text { sufficient lighting and visual aid devices are important. The most important safety } \\
\text { feature is that the whole construction zone is well lighted using ample floodlight. } \\
\text { By doing so, not only will it help the workers to do their work, the road users will } \\
\text { also be aware of such activity going on due to the bright nature of the works and } \\
\text { will be more careful when passing through. In addition to that, the road users must } \\
\text { also be well alarmed of the works going on ahead of them with the use of visually } \\
\text { vibrant and attracting signs, delineators and devices. }\end{array}$ \\
\hline
\end{tabular}




\subsection{The main problems of night-time highway construction or maintenance/ upgrading works}

Table 5: Main problems faced

\begin{tabular}{|c|c|l|}
\hline $\begin{array}{c}\text { Ranking } \\
\text { No. }\end{array}$ & Theme & \multicolumn{1}{c|}{ Explanation } \\
\hline \multirow{1}{*}{1} & $\begin{array}{l}\text { Hazard from } \\
\text { road users }\end{array}$ & $\begin{array}{l}\text { According to the interviews conducted, most of the respondents have highlighted } \\
\text { that apart from the visibility issues of night-time highway construction or } \\
\text { maintenance/upgrading works, one of the main problems of night-time highway } \\
\text { construction or maintenance/upgrading works is the road users themselves. Since } \\
\text { traffic is quite low during the night, road users tend to drive their vehicles and ride } \\
\text { their bikes much faster at night. These with the addition of drunk drivers and also } \\
\text { drowsiness have definitely increased the danger factor when conduction } \\
\text { construction works at night-time. Even after all the safety measures along with } \\
\text { ample lighting devices are used, road users are driving too fast might still be unable } \\
\text { to control their vehicles when arriving at the construction zone and accident might } \\
\text { still happen. This factor is way out of the contractor's and authorities hand and is } \\
\text { all up to the road users themselves. }\end{array}$ \\
\hline
\end{tabular}

\section{Conclusion}

Based on the data collection and analysis, one of the main purposes of conducting highway construction or maintenance/upgrading works at night is to cut down the construction period. Nighttime construction is particularly useful when dealing with projects with short periods or for projects that need to be completed in a hurry, such as when nearing public holidays or festive seasons. By conducting works both day and night, construction or maintenance/upgrading works can be completed at a much shorter period compared to if the works were conducted during daytime only.

Other than that, in some highway construction or maintenance/upgrading work zone, the works can only be conducted at night-time only. This is mainly due to avoid traffic congestion problem from occurring if such works to be conducted during daytime. Other than that, transportation works and works involving large machineries are easier to be conducted at night due to low traffic volume.

When talking about the aspects of safety, it is concluded that contractors should emphasize in ensuring that the work zone is properly lighted and that signs, delineators and the workers themselves are clearly visible to the road users. Productivity of night-time works is a direct result of what impact working at night will have towards the physical and mental well-being of the workers. This means that productivity of workers working in night-time will become low because they might be too tired working since the morning or in other cases the workers feeling uncomfortable working at night since night-time is usually spent to be with family and resting. In terms of quality of works, it is determined that the quality of night-time works is as according to the original specification and will not have an impact towards the works.

The main problem working at night, apart from the lighting and visual issues mentioned earlier, the road users at night themselves tend pose a threat towards the safety of the construction workers, mainly due to drowsiness, driving at high speed and also driving under the influence.

\section{References}

1. Gannapathy,V.R,Subramaniam,S.K,MohamadDiah,A.B.,Suaidi, M.K. and Hamidon, A.H. (2011).Flagman and risk involved in road construction site, International Journal of Sustainable Construction Engineering \& Technology, 2011, pp. 113 - 118

2. Abraham, D. M., Spadaccini,J. J., Burgess,B.B., Miller,L.R., and Valentin, V. (2007).Evaluating and enhancing the safety of nighttime construction projects, Publication FHWA/IN/JTRP2007/14. Joint Transportation Research Program, Indiana Department of Transportation and Purdue University, West Lafayette, Indiana. 
3. Hinze, J.W. and Carlisle, D. (1990), An evaluation of the important variables in night-time construction, Transportation Northwest, Department of Civil Engineering, University of Washington, Seattle, WA.

4. Elrahman, O.A. (2008), Night-time Road Construction Operations: Synthesis of Practice, Transportation Research and Development Bureau, New York State Department of Transportation, Albany, NY.

5. Ellis, R.D., Herbsmann, Z.J.,Chheda, P.N., Epstein, W.C., and Kumar, A. (1993).Developing Procedures for Night Operations of Transportation Projects, Transportation Research Center, University of Florida, Gainesville, Florida, January 1993.

6. Colbert, D.A. (2003) Productivity and Safety Implications of Night-Time Construction Operations, Independent Research Study Report, Purdue University, West Lafayette, Indiana.

7. Park, S., Douglas,K.D.,Griffith,A.S., and HaasK.J. (2001).Factors of Importance for Determining Day-time versus Night-time Operations in Oregon, 81st Annual Meeting of the Transportation Research Board, Washington, D.C.

8. Al-Kaisy, A., and K. Nassar (2002).Night-time Construction Issues Revisited, 82nd Annual Meeting of the Transportation Research Board, Washington, D.C.

9. Price, D.A. (1986).Nighttime Paving, Washington, D.C.: Colorado Deptartment of Transportation for Federal Highway Administration.

10. Carpentier, J., and Cazamian, P. (1977). Night work: Its effect on the health and the welfare of the worker, International Labor Office, Geneva, Switzerland.

11. Holguin-Veras, J., Baker, R., Medina,A.,and Sackey,D. (2001).An Analysis of Human Factors at Night-time Work Zones, City College of New York, New York, New York. 